http://dx.doi.org/10.12775/LinCop.2015.001

Izabela Duraj-Nowosielska

Uniwersytet Mikołaja Kopernika

Instytut Języka Polskiego

\title{
Gdzie jest cel w zdaniach z celowo i kilka innych pytań o wyrażenia pokrewne*
}

Słowa klucze: bez celu; bezcelowo; bezcelowy; celowo; celowy; działanie; niecelowo; niecelowy; intencjonalność; przymiotnik; przysłówek; semantyka

Ke y word s: bez celu; bezcelowo; bezcelowy; celowo; celowy; niecelowo; niecelowy; on purpose; purpose; purposefully; action; adjective; adverb; intentionality; semantics

1. Proponuję poniżej przyjrzeć się kilku polskim wyrażeniom ze słowem cel: przysłówkom celowo, niecelowo, bezcelowo i bez celu, a także odpowiadającym im przymiotnikom celowy, niecelowy i bezcelowy, które - jako że odnoszą się do znominalizowanych działań - należy uznać za semantycznie wtórne względem przysłówków. Interesować nas będą przede wszystkim relacje pomiędzy wymienionymi tu wyrażeniami, a także pewne regularne charakterystyki semantyczne dające o sobie znać w tej grupie; kwestię

* Artykuł na podstawie referatu wygłoszonego na VI Kolokwium Semantycznym, Warszawa, UW, 15.12.2014. 
szczegółowej semantyki samej jednostki cel, jak również problem jej relacji do tych wyrażeń, pozostawiam tu na boku ${ }^{1}$.

Pytanie wyjściowe brzmi: jaki cel ma na myśli nadawca zdań ze słowem celowo? Czy w zdaniu:

(1) Jan celowo jej mówił takie rzeczy.

chodzi o to, że samo mówienie czegoś było tym orzeczonym celem, czy może ów wyznaczony w zdaniu cel sięgał dalej, poza mówienie? Jak sądzę, zgodzimy się, że przykład (1) wskazuje na dalszy cel podmiotu, por. zdanie:

(2) ? Po co Jan celowo mówił jej takie rzeczy?,

którego intuicyjna dewiacyjność bierze się stąd, że wyrażenia po co i celowo zajmują tę samą pozycję składniową. Owszem, możemy uzupełnić (1) zdaniem celowym:

(3) Jan celowo jej mówił takie rzeczy - żeby ją zdenerwować.,

jednak pod warunkiem, że uzupełnienie celowe potraktujemy jak dopowiedzenie, precyzację znaczenia przysłówka (tak jak to sugeruje zastosowana tu interpunkcja).

Wstępnie można przyjąć taką oto (uproszczoną, zob. przyp. 3) formułę semantyczną dla zdania jądrowego z wyrażeniem celowo:

1 To ostatnie wiąże się z istotnym pytaniem, na ile postulowane zależności semantyczne muszą się opierać na zależnościach morfologicznych. Zdarza się, że bardzo ciekawe propozycje semantyczne biorą się właśnie z uniezależnienia od siebie tych relacji: może się wówczas okazać, że zależność semantyczna przebiega w odwrotnym kierunku niż domniemana zależność morfologiczna. (Przykładem niech będzie chociażby tzw. negacyjna teoria aspektu [Bogusławski 2003], w której aspekt niedokonany jest zawsze, niezależnie od struktury morfologicznej, nabudowany na dokonanym; jest to teoria czysto semantyczna, stąd być może trudna do przyjęcia dla niektórych aspektologów, przywiązujących wagę do morfologicznej budowy par aspektowych i do historycznego kierunku derywacji.) Jeśli chodzi o jednostkę cel, to jest ona wysoce abstrakcyjnym korelatem semantycznie i „bytowo” złożonej sytuacji (por. na ten temat klasyczną monografię M. Grochowskiego 1980), tym bardziej więc kierunek zależności semantycznych w polu pokrewnych jej wyrażeń nie wydaje się oczywisty. 


\section{$x$ robi / zrobil p}

ix robi / zrobit p po to, żeby (robieniem p) spowodować (jakieś) q, takie, że nie jesteśmy gotowi powiedzieć, że jeśli p to (koniecznie) q.

Ostatnia linijka formuły jest wyrazem nasuwającego się tu zastrzeżenia tematycznego, zgodnie z którym orzeczenie celu czynności musi mieć po prostu jakiś pragmatyczny sens; jeżeli dany cel jest naturalnie wpisany w czynność, o której mowa w zdaniu, nie użyjemy w odniesieniu do niego słowa celowo, jak w:

(4) ? Był zmęczony, dlatego celowo na chwilę usiadł.

Oczywiście, konkretne konteksty sytuacyjne są w stanie nawet znacznie zmodyfikować dopuszczalną interpretację tego, co uznaje się w danym wypadku za „naturalny cel” czynności, stąd dla poszczególnych akcji możemy podać tylko ogólne warunki początkowe. Podstawowa zasada pozostaje jednak w mocy: nie może tu chodzić o cel ,zrozumiały sam przez się”, czy to zrozumiały na podstawie ogólnych semantycznych właściwości czasownika, czy też zrozumiały z danych sytuacyjnych ${ }^{2}$.

2. Jeśli chodzi o strukturę tematyczno-rematyczną zdań z celowo, to sugeruję - odpowiada ona ogólnej strukturze zdań z przysłówkami, które można nazwać ,intencjonalnymi”, tj. wskazującymi na intencjonalne działanie podmiotu, takimi jak specjalnie, świadomie czy rozmyślnie (zob. o tym np. Duraj-Nowosielska 2012). Mam tu na myśli neutralne zdania z tym przysłówkiem, mianowicie takie, które mają szansę zaistnieć bez wcześniejszego kontekstu zdaniowego. Wydaje się, że w zdaniach izolowanych (od kontekstu - na tyle, na ile jest to możliwe ${ }^{3}$ ) przysłówki tego rodzaju stanowią remat zda-

2 Ponadto po to, żeby jest oczywiście samo w sobie konstrukcją celową, którą można najpewniej dalej semantycznie rozkładać; tutaj pozostawiam ją w takiej formie, gdyż, jak zaznaczałam, zależy mi głównie na uchwyceniu pewnych różnic pomiędzy wyrażeniami „odcelowymi”.

3 Zdaję sobie sprawę, że idea „zdań izolowanych” to poważny punkt sporny w dyskusji nad strukturą tematyczno-rematyczną wypowiedzi i jej wpływem na semantykę użytych tam wyrażeń (tu odnoszę się m.in. do dyskusji nad referatem, por. przyp. 1). Mój tok rozumowania streściłabym następująco: To jasne, że wypowiedziane zdania są zawsze elementami konkretnych aktów mowy, z konkretnymi determinantami sytuacyj- 
nia równoległy z jakimś innym rematem, co znajduje wyraz w formie eksplikacji, gdzie dwóm rematom zdania wyjściowego odpowiadają dwa połączone równolegle zdania po stronie definiensa. W takim układzie czasownik nie jest tematem dla przysłówka (tzn. nie jest na najwyższym piętrze eksplikacji), bo obydwie te rzeczy orzeka się niezależnie - to, że ktoś coś zrobił, oraz to, że zrobił to po cośt .

nymi. Na ogół też wypowiadamy zdania w ciągach zdaniowych, i obydwa te czynniki kon-sytuacyjny oraz kon-tekstowy - bezsprzecznie wpływają na strukturę tematyczno-rematyczną wypowiedzeń. Wychodząc zatem od możliwych konfiguracji tematyczno-rematycznych, można powiedzieć, że nie ma żadnej „uprzywilejowanej” struktury, bo każda z nich odpowiada konkretnym - nazwijmy je - zapotrzebowaniom kontekstowym. Z drugiej strony, szukając inwariantów semantycznych danych wyrażeń, nie jesteśmy w stanie odtworzyć nawet znikomej części kontekstów i sytuacji, w których mogą one zostać użyte. Co więcej, nie byłoby to wcale wskazane, bo duża część tych kontekstów będzie (często w mało zauważalny sposób) modyfikowała wyjściowe znaczenie wyrażenia, na zasadzie niepohamowanej dążności odbiorcy do uspójnienia czy wręcz wyratowania wypowiedzianego zdania, o ile nie zostanie ono odwołane przez samego nadawce (por. dyskusję na ten temat w: Duraj-Nowosielska 2013). Stąd w analizie semantycznej trzeba by brać pod uwagę przede wszystkim wyrażenia występujące w maksymalnie neutralnych kontekstach, zarówno zdaniowych, jak i sytuacyjnych. Dotyczy to zwłaszcza decyzji akceptowalnościowych $w$ testach negacji, które zupełnie tracą na znaczeniu z chwilą, kiedy z uporem zaczynamy poszukiwać kontekstów uspójniających dla zdań watpliwych.

I tak dla semantyka - z konieczności miłośnika inwariancji - takim (względnym) gwarantem neutralności kontekstowej byłaby właśnie idea zdania izolowanego, co należy rozumieć: zdania możliwie izolowanego, izolowanego w miarę możliwości... Jeżeli takie zdanie da się wypowiedzieć, będzie ono miało swoją własną STR, którą tym samym można uznać za neutralnq STR zdania z danym wyrażeniem. Takie zdanie traktowałabym jako punkt wyjścia $w$ analizie semantycznej, toteż jeśli pewne typy wyrażeń wykazują zauważalną regularność, jeśli chodzi o „zdania neutralne”, jest to w moim rozumieniu wystarczający powód, by ten fakt odnotować. Może się on okazać (choć nie musi) semantycznie istotny, o ile uda się powiązać te właściwości z tym, co niezależnie od nich można o danym wyrażeniu powiedzieć (małą próbę tego rodzaju dla przysłówków ,intencjonalnych" i „nieintencjonalnych” podjęłam w: Duraj-Nowosielska 2012). Nawet jeżeli nie uda się tego zrobić i „neutralna STR” okaże się (w danej chwili być może) bez większego znaczenia dla semantycznego obrazu wyrażenia, to zawsze pozostaje podstawowe rozróżnienie wyrażeń prymarnie / inherentnie rematycznych / tematycznych (por. Bogusławski 1999); bez pojęcia „zdania neutralnego”, jak przypuszczam, nie dałoby się odróżnić wyrażenia „prymarnie tematycznego” od wyrażenia ,prymarnie rematycznego", bo każde z nich może też występować w roli drugiego.

${ }_{4}^{4}$ Odpowiadając na wątpliwości Recenzenta, zaznaczę, że aparatura wypracowana przez A. Bogusławskiego (1977), która jest dla mnie faktycznie podstawowym punktem odniesienia, jak najbardziej dopuszcza obecność dwóch równoległych rematów w zda- 
Remat zdania jest naturalnie tym elementem, który nosi główny akcent zdaniowy. W zdaniach izolowanych z celowo oprócz przysłówka akcentowany będzie na ogół czasownik, ale rzecz jasna może to być też inny składnik wypowiedzenia, np.:

(5a) Jan celowo mówil Kasi przykre rzeczy <>

(5b) Jan celowo mówił przykre rzeczy Kasi.

Jako zdania dwurematyczne różnią się one istotnie od zdań z przysłówkami „nieintencjonalnymi”, takimi jak niechcacy czy nieświadomie, gdzie w neutralnych kontekstach przysłówki typowo wchodzą do części tematycznej, por.:

(6a) Zenon niechcący wyrwal drzwi z zawiasów $<>$

(6b) Zenon specjalnie wyrwał drzwi z zawiasów $<>$

(6c) ? Zenon specjalnie wyrwal drzwi z zawiasów.

Oczywiście, zdanie (6c) jest możliwe do wymówienia, ale będzie ono wówczas odpowiedzią na pytanie z eksplicytnie wybranym tematem (wg terminologii A. Bogusławskiego 1977: 265) (Co Zenon zrobit specjalnie?); takie zdania odznaczają się specjalnym konturem intonacyjnym i nie maja szans uniezależnić się od kontekstu. Na tej samej zasadzie możliwe są też zdania $\mathrm{z}$ rematyzowanym samym przysłówkiem:

(6d) Zenon specjalnie wyrwał drzwi z zawiasów -

tutaj z kolei tematyzowane jest całe zdanie, co daje kontur wyraźnie wtórny względem (6b); zdania tego typu pozostają zawsze zależne od wcześniejszego kontekstu wypowiedzi.

niu, obok zasadniczej hierarchizacji STR. (Por.: „The themes may be equiponderant or unordered. Their theme may be one [...] or there may be more than one theme" [Bogusławski 1977: 300].) Zdania dwurematyczne są zresztą zjawiskiem od dawna znanym w opisie językowym - taką właściwość mają np. konstrukcje z przydawkami orzekającymi (por. Klemensiewicz 1968: 65). Nie ma tu znaczenia fakt, że jakieś inne przysłówki będą typowo tematyzowały czasownik. 
Oto kilka innych zdań, przeznaczonych do odczytania na głos. W każdym punkcie jeden przykład z pary przysłówkowej (przysłówek ,intencjonalny” - „nieintencjonalny”), zaznaczony kursywą, jest przykładem autentycznym, zaczerpniętym z prasy lub internetu ${ }^{5}$ :

(7a) Anglicy nieumyślnie zboczyli z drogi $<>$

(7b) Anglicy umyślnie zboczyli z drogi $<>$

(7c) ? Anglicy umyślnie zboczyli z drogi ${ }^{6}$

(8a) Staruszek przypadkiem dodal gazu i po chwili znalazt się w rowie $<>$ / I I

(8b) Staruszek celowo dodał gazu i po chwili znalazł się w rowie $<>$

(8c) ? Staruszek celowo dodał gazu i po chwili znalazł się w rowie

(9a) Sam nieświadomie przykktadat rękę do zagrożeń, jakie czyhały wokót $\diamond$ / /

(9b) Sam świadomie przykladał rękę do zagrożeń, jakie czyhały wokół $<>$ / /

(9c) ? Sam świadomie przykładał rękę do zagrożeń, jakie czyhały wokół

(10a) Moi sqsiedzi nieświadomie przyjmowali zasadę: „inny to znaczy gorszy" $<>$

(10b) Moi sąsiedzi świadomie przyjmowali zasadę: „inny to znaczy gorszy" $<>$

5 Taki zapis obowiązuje w całym tekście (kursywa w przykładach autentycznych). Zupełnie na marginesie dodam (ponownie odpowiadając na uwagę Recenzenta), że pisownię 'internet' stosuję świadomie - słowo to z pewnością funkcjonuje obecnie na prawach rzeczownika pospolitego, wskazuje nie na jedną konkretną Sieć, lecz na „sieć sieci”, czy wręcz pewien typ narzędzia, a pisownia wielką literą wydaje się nieuzasadnioną kalką ortograficzną z języka angielskiego. Pozostając przy wielkiej literze, należałoby chyba konsekwentnie napisać: „... zaczerpniętym z Prasy lub Internetu”.

6 Ukośną kreską oznaczam rematy „ostateczne”. 
(10c) ? Moi sąsiedzi świadomie przyjmowali zasadę: „inny to znaczy gorszy".

Problemu własności akcentowych zdań z przysłówkami ,intencjonalnymi” i „nieintencjonalnymi” nie będę w tym miejscu rozwijać (odsyłam do cytowanej w przyp. 4 publikacji) - w każdym razie jednostka celowo (chociaż już nie niecelowo, o czym będzie mowa za chwilę) w ten schemat moim zdaniem się wpisuje.

Jak wspomniałam w przypisie 5 , zdania z przysłówkami intencjonalnymi przypominają strukturę zdań z przydawkami orzekającymi - i podobnie jak w tych ostatnich nadawca mówi o tym, co zrobił podmiot, a jednocześnie mówi jeszcze coś o samym podmiocie (coś, co towarzyszyło temu robieniu), tak i tutaj oprócz samego działania podmiotu, realizowanego „na zewnątrz", wydobywa się to, co podmiot ma ,wewnątrz" siebie, czyli jego pobudki, motywacje. Nadawca chce za pomocą odpowiedniego przysłówka obciążyć podmiot odpowiedzialnością, a często wprost obarczyć go winą istotnie, duża część kontekstów dotyczących przysłówków „intencjonalnych” wskazuje na coś, co jest w powszechnym odczuciu odbierane jako przewinienie. To, co zrobił podmiot, podlega najczęściej ocenie negatywnej, a jest tak po prostu dlatego, że głównie takie czyny domagają się wyjaśnień: jeśli ktoś komuś wyrządził jakieś dobro, normalnie nie szukamy motywów, zakładamy raczej, że ludzie chcq sobie świadczyć dobro. Wyrażenie celowo nie jest wyjątkiem, jeśli chodzi o tak scharakteryzowane pragmatyczne zaplecze wypowiedzi ,intencjonalnych”. W zdaniu:

(11a) Jan celowo pomógł Kasi w lekcjach

automatycznie będziemy się dopatrywać „drugiego dna”, tj. innego celu niż taki, żeby Kasia (na przykład) dobrze sobie poradziła na lekcji. Por. (11a) $\mathrm{z}$ dobrym, niedziwnym zdaniem:

(11b) Jan celowo jej wtedy nie pomógł.

(Omawiałam ten problem obszerniej przy okazji analizy przysłówka niechcacy w: Duraj-Nowosielska 2012.) 
3. Powrócę teraz do pytania, jaki cel może mieć na myśli nadawca w zdaniach ze słowem celowo. Gdyby $x$ celowo zrobił $p$ oznaczało „p było celem x-a", zdania takie jak:

(12) Jan celowo powiedział Kasi o tym wydarzeniu

(13) Jan celowo namawiał Kasię do tego wyjazdu

byłyby odbierane jako tautologiczne. Jednak tak nie jest, co przemawiałoby za tym, że nadawca upatruje ów cel gdzieś dalej, poza tym, co wyrażone w zdaniu. Tak to przynajmniej wygląda w przykładach dyskutowanych do tej pory. Ale już na przykład w zdaniu:

\section{(14) Jan celowo ją wtedy denerwował / zdenerwował}

interpretacja, że to właśnie zdenerwowanie x-a było wyznaczonym przez podmiot celem, o którym mowa, wręcz się narzuca.

Najwyraźniej wiele tu zależy od użytego w zdaniu czasownika. Jeśli mamy do czynienia z predykatem wyrażającym czynności ewidentnie intencjonalne, tzn. takie, że wola spowodowania określonego skutku jest w jakiś sposób wpisana $\mathrm{w}$ ich znaczenie, to $\mathrm{w}$ zdaniach $\mathrm{z}$ przysłówkiem celowo od razu wychodzimy w kierunku „dalszych” celów. Dzieje się tak prawdopodobnie dlatego, że w przypadku tego rodzaju czasowników nie ma potrzeby ustalania, czy dana w zdaniu czynność była czy nie była sama $w$ sobie intencjonalna. Klasa takich czynności zapewne w dużej mierze będzie się pokrywać z tzw. operacjami (por. Bogusławski 1991), chociaż można przyjąć, że w interpretowaniu celu założona przez odbiorcę intencjonalność czynności będzie raczej kwestią stopnia, tzn. są operacje, w których nieintencjonalność jest zasadniczo wykluczona (np. namówić kogoś do czegoś, porozktadać coś itd.), a są też i takie, co do których odbiorca będzie się wahał, o ile nie zostaną mu dostarczone dodatkowe dane kontekstowe (np. przesunqć coś).

Co ciekawe, podobnie (aczkolwiek z innego powodu) rzecz się ma z tzw. akcjami, czyli czynnościami wyrażanymi czasownikami bezobiektowymi lub czasownikami z quasi-obiektami, odnoszącymi się przede wszystkim do podstawowych czynności ruchowych człowieka, czy inaczej - „czynności 
prostych"7, co do których zasadniczo nie pytamy się, na ile były wykonywane intencjonalnie. Tak więc w zdaniu:

\section{(15) Jan machnął ręką}

normalnie nie zadajemy sobie pytania, do jakiego stopnia było to działanie świadome, umyślne itp. (zwrócił niegdyś na to uwagę Austin [1977], wbrew ówczesnej tendencji do objaśniania „robienia czegoś” za pomocą odrębnych predykatów wolitywnych). W sytuacji, kiedy decydujemy się orzec celowość tej akcji:

(15a) Jan celowo machnął ręką,

automatycznie otwieramy perspektywę dalszego celu, co oznacza, że musimy być przygotowani na pytanie: po co Jan machnął ręką? Wyklucza to z jednej strony zdania typu:

(16) ? Jan siedział na kanapie i celowo machał sobie noga,

w którym charakterystyczna celownikowa forma zaimka (zbliżająca tę konstrukcję do formacji tzw. determinatywnych w słowotwórstwie ${ }^{8}$ ) zamyka niejako celowość akcji w obrębie samego podmiotu.

$\mathrm{Z}$ drugiej strony nic nie stoi na przeszkodzie, by powiedzieć na przykład:

(17) Jan celowo bębnił palcami o stół - dawał w ten sposób do zrozumienia, że jest zdenerwowany,

gdzie upatruje się celu poza wyrażoną w zdaniu czynnością. (Gdybyśmy jednak w podobny sposób uzupełnili zdanie [16], na przykład [według sugestii Recenzenta]: Jan siedziat na kanapie i celowo machat sobie noga, bo chciat $w$ ten sposób okazać swojq dezynwolturę i obojętność wobec przedmiotu to-

7 Zob. na ich temat np.: Hampshire 1959, Danto 1963, Davidson 1966, Searle 1983, Ryle 2000.

8 Por. Wróbel 1999: 546. Konstrukcje tego typu (Odpocznij sobie) bywają włączane - chyba niesłusznie - do wspólnej klasy z konstrukcjami typu Ja ci dam. Popraw mi się jako przykłady użycia dativi ethici (por. odpowiednie hasło w EJP). 
czqcej się rozmowy, sprzeniewierzylibyśmy się tym samym semantyce „machania sobie czymś”. Ostatecznie wyszłoby na to, że Jan tylko udawał, że macha sobie nogą, a tymczasem machał nogą właśnie w konkretnym celư ${ }^{9}$.)

Sądzę, że ta cecha zdań akcyjnych bierze się stąd, że pojęcie celowości narzuca sytuacji pewną złożoność. Chodzi w nim zawsze o jakiś proces (żeby można było mówić o celu, muszą istnieć jakieś środki do niego prowadzące, jakieś „etapy pośrednie”), toteż jeśli mamy do czynienia z tzw. czynnością prostą, wybierzemy jedną z dwóch możliwości interpretacyjnych: albo poszukamy tej złożoności gdzieś dalej, poza czynnością wyrażoną w zdaniu (i to jest pierwsza narzucająca się interpretacja, jak w [15a]), albo czynność, którą normalnie odbieramy jako prostą, zaczniemy traktować jako czynność złożoną. Tak więc możemy sobie wyobrazić kogoś, kto np. po jakimś urazie ma problemy z kontrolowaniem ruchów rąk - to znaczy z jednej strony rusza nimi w sposób niekontrolowany (one $m u$ się ruszają), a z drugiej strony ma trudności ze świadomym ich poruszeniem, poruszeniem „na zawołanie”. W takiej sytuacji zdanie $X$ celowo machnat rękq nabiera naturalnie innego sensu niż w zwykłej interpretacji: orzeczenie staje się wyrażeniem operacyjnym, a ręka - „zwyczajnym” obiektem (celowego) działania ${ }^{10}$.

3.1. W ten sposób interpretowane są zdania z czasownikami intencjonalnymi (operacyjnymi) i czasownikami nazywającymi czynności proste. Tymczasem jeśli orzeczenie w zdaniu jest wyrażeniem odkauzatywnym (tak jak w przykładzie [14] z predykatem zdenerwować ${ }^{11}$ ), tzn. takim, gdzie punktem wyjścia jest jakiś skutek w rzeczywistości i sam czasownik nie sugeruje, czy ktoś doprowadził do tego skutku intencjonalnie, czy nie (zwłaszcza że mówimy o zdaniach izolowanych) ${ }^{12}$, pytanie o ogólnie pojętą intencjonalność jest

9 Por. z: + Jan siedzial na kanapie i celowo machat nogq, bo chciat $w$ ten sposób okazać swoja dezynwolturę i obojętność wobec przedmiotu toczacej się rozmowy, analogicznym do (17).

10 Szerzej ten problem dyskutowałam w związku z książką psychiatry Olivera Sacksa (1996) w: Duraj-Nowosielska 2007: 226.

11 Oczywiście, nie wszystkie wyrażenia kauzatywne z podmiotami osobowymi na powierzchni mogą współwystępować z celowo; jest to zresztą dobry test na agentywizację czasownika, por. (14) i np.: *On celowo wprawit ja wtedy w ostupienie.

$12 \mathrm{~W}$ ogóle nie musi to być podmiot osobowy (lecz sytuacyjny - coś) i w większości wypadków pierwotnie właśnie nie jest, zob. na ten temat Duraj-Nowosielska 2007. 
pewnie pierwszym pytaniem, które odbiorca zdań z podmiotami osobowymi sobie zadaje. Por.:

(18) Jan stłukł wazon $<>$ (18a) Jan celowo stłukł wazon.

(19) Jan potrącił Kasię <> (19a) Jan celowo potrącił Kasię.

Zdania (a) rozumiemy przede wszystkim tak, że Jan chciał zrobić to, na co one wskazują.

Widzę tutaj dwie możliwości interpretacyjne. Po pierwsze możemy przyjąć, że w zdaniach tych wyrażenie celowo mimo wszystko kryje jakiś dalszy cel, pragmatycznie natomiast wydobywa się w nich to, co jest konsekwencja tego założenia, czyli to, że jeśli x zrobił p po to, żeby osiągnąć jakieś q (niewyrażone $\mathrm{w}$ zdaniu), to $\mathrm{x}$ musiał chcieć zrobić $\mathrm{p}$. Na tej zasadzie $\mathrm{w}$ zdaniu (14) wnioskowalibyśmy, że „ona” była obiektem (intencjonalnej) „czynności denerwowania”, a zatem także i to, że podmiot robił coś, żeby to osiągnąć (osiągnąć $\mathrm{p}$ wyrażone $\mathrm{w}$ zdaniu). Łańcuch wnioskowania byłby $\mathrm{w}$ takim wypadku wyraźnie dłuższy niż w typowych zdaniach akcyjnych czy operacyjnych.

Zasadniczo jednak w tej pierwszej interpretacji zdania takie jak (14), (18a) i (19a), podobnie jak zdania akcyjne i operacyjne dyskutowane wcześniej, sięgają, jeśli chodzi o wskazany w nich cel, poza to, co same wyrażają (czyli odwołują się do „dalszego” celu) - rozumiemy, że np. w (19a) Jan potrącił Kasię po to, żeby spowodować jakieś inne, nieokreślone w zdaniu q. Chodziłoby tu zatem jedynie o coś w rodzaju kontekstowo-pragmatycznego przesunięcia punktu ciężkości. Co prawda, wydaje się, że łatwo tej interpretacji można zaprzeczyć, mówiąc na przykład:

(18b) Jan stłukł ten wazon celowo, ale niczego nie chciał przez to osiągnąć, zrobił to ot tak sobie -

jednak eksplicytne wykluczenie wszelkich możliwych celów tym sposobem (przy użyciu „zwykłego” testu negacji) jest chyba niemożliwe, gdyż takie zdania jak (18b) od razu zaczynamy rozumieć w ten sposób, że podmiot chciał coś zrobić np. dla żartu albo z czystej złośliwości - a więc zrobił to jednak po coś. Za pomocą tego rodzaju zdań jesteśmy więc w stanie wyeliminować tylko pewne konkretne cele łatwe do sprecyzowania, dlatego nie są one 
dobrym argumentem przeciwko sugerowanej tu interpretacji. Nie twierdzę, że jest to interpretacja właściwa, ale z pewnością jest warta rozważenia, skoro scala semantykę celowo dla trzech różnych typów czasowników (pierwotnie akcyjnych, pierwotnie operacyjnych i odkauzatywnych).

W interpretacji konkurencyjnej trzeba by uznać, że tego rodzaju zdania po prostu zawieraja q, czyli skutek działania, będący zarazem właściwym celem podmiotu. Przyjmujemy w takiej sytuacji, że zdania z predykatami odkauzatywnymi wyrażają q, a samo p pozostaje ukryte, przy czym p ma wyrażać to, co podmiot robił bądź na zasadzie akcji/operacji intencjonalnej, bądź na zasadzie akcji związanej z jego własnym ciałem (w konstrukcjach agentywnych zawsze się ostatecznie do tego odnosimy ${ }^{13}$ ). W takim rozumieniu $x$ zdenerwowat $y$ - $a$ oznaczałoby: x przez to, że zrobił jakieś $\mathrm{p}$ (niewyrażone w zdaniu, np. coś powiedział), spowodował q (zdenerwowanie y-ka). Struktura semantyczna celowo w odniesieniu do tego punktu wyglądałaby wtedy tak:

\section{ox-e, który zrobil (spowodowal) q: $x$ zrobit jakieś p po to, żeby spowodować q,}

gdzie wyjściowa czynność p pozostaje nieokreślona, o ile nie zostanie sprecyzowana osobno.

3.2. Za drugą podaną tu interpretacją, uzależniającą lokalizację celu od typu czasownika, przemawiałoby zaprzeczenie tego przysłówka. Zdanie:

(20) On ją zdenerwował, ale nie celowo

rozumiemy przede wszystkim tak, że zdenerwowanie y-ka nie było celem podmiotu: x zrobił jakieś p (np. coś powiedział) nie po to, żeby spowodować q (wyrażone w zdaniu). Podobnie w zdaniu:

(21) Stłukł wazon, ale nie celowo

13 ...jak to wyjaśniałam obszernie w przywoływanej tu już pracy: Duraj-Nowosielska 2007. 
wydaje się, że abstrahujemy od ewentualnych innych celów wychodzących poza stłuczenie wazonu i skupiamy się na celowości samego tego zdarzenia.

Owszem, moglibyśmy postarać się zbudować taki kontekst wypowiedzi, który pozwalałby na interpretację z dalszym celem. Moglibyśmy na przykład powiedzieć: Stlukt wazon, ale nie celowo w sytuacji, gdy przewidujemy, że stłuczenie wazonu będzie przez kogoś odebrane jako rodzaj sygnału; z tym, że jest to raczej nadzwyczajna interpretacja, wymagająca specyficznego kontekstu.

Jak można się spodziewać, odwrotnie rzecz się będzie przedstawiała w przypadku „zwykłych” czasowników działaniowych (operacyjnych), a także czasowników akcyjnych. W zdaniu:

(22) Jan napisał ten list, ale nie celowo

nie mówimy oczywiście, że to, co robił Jan (trzymał w ręku długopis i poruszał nim nad kartką papieru), nie miało na celu napisania listu. Negujemy tu istnienie właśnie jakiegoś dalszego celu, który tym razem - jak się wydaje musi być określony dla uczestników aktu mowy. Innymi słowy, konstrukcja „ktoś coś zrobił, ale nie celowo” odnosi się do jakiegoś pomyślanego możliwego celu, inaczej niż w zdaniach twierdzących, w których cel może pozostać nieokreślony (stwierdza się tylko jego istnienie). Podobnie w zdaniu cytowanym z prasy:

(23) Zakonnica biła, ale nie celowo

rozumiemy, że zakonnica niczego przez to (co robiła) nie chciała osiągnać; z kolei zdanie:

(24) Jan bębnił palcami o stół, ale nie celowo ${ }^{14}$

14 Zgłaszane wątpliwości co do pisowni rozdzielnej nie celowo w tych zdaniach są, przyznam, dla mnie niezrozumiałe (co - mam nadzieję - wyjaśni się, kiedy będzie mowa o przysłówku niecelowo). Por. np. (24) z: Jan bębnit palcami o stót, choć robił to zupetnie niecelowo. Pisownia łączna / rozdzielna ściśle przekłada się też na akcentuację wyrazów: niecelowo vs. nie celowo. Pisownię (23) zachowuję zresztą oryginalną, inna by się moim zdaniem w tym kontekście nie tłumaczyła. 
będziemy interpretowali tak, że podmiot nie chciał na przykład niczego przez bębnienie palcami dać do zrozumienia, robił to „ot tak sobie”.

4. Analogiczne zależności obserwujemy przy nominalizacjach, w których przechodzi się od przysłówka do morfologicznego przymiotnika. Także i tutaj dużo zależy od samego czasownika. Fragment zdania $\mathrm{z}$ tekstu prawniczego:

(25) Celowe niszczenie cudzej własności...

rozumiemy tak, że ktoś „,celowo niszczył” cudzą własność, czyli celem było właśnie zniszczenie. $Z$ drugiej strony, w zdaniu:

(26) Podjął w związku z tym różne celowe działania

chodzi o to, że x podjął działania p z określonym celem q; same te działania były nakierowane na jakiś cel.

Nie można jednak powiedzieć, że czasownik jest tu w pełni rozstrzygający - stanowi on tylko (wprawdzie dość mocną) poszlakę interpretacyjną. Samo połączenie działanie celowe wydaje się dwuznaczne, tzn. albo jest to działanie nakierowane na cel, jak w przykładzie (26), albo takie, które samo jest celem; zdanie:

(27) To było z jego strony celowe działanie

interpretujemy właśnie tak, że podmiot chciał zrobić to, co zrobił - to był jego cel (niewykluczone też, że na interpretację tego połączenia ma wpływ jego wewnętrzny szyk: działanie celowe vs. celowe działanie).

Podsumowując tę część: w zdaniach z celowo, celowy daje się zauważyć dwuznaczność pomiędzy tym, co można nazwać „,celem wewnętrznym”, wyznaczonym w zdaniu, a „,elem zewnętrznym” wobec tego, na co się w zdaniu bezpośrednio wskazuje; w obydwu wypadkach chodzi oczywiście o cel myślany przez sam podmiot działania. W dużej mierze, jak ustaliliśmy, interpretacja zależy od typu czasownika, aczkolwiek czasownik nie gwarantuje stuprocentowej jednoznaczności i mogą tu dochodzić do głosu 
również inne czynniki (kontekstowe, składniowe [jak w (26)-(27)] czy prozodyczne - o tych ostatnich wspomnę pokrótce dalej).

5. Rzecz ciekawa, w przymiotniku celowy nakłada się na to rozróżnienie jeszcze jedna regularna dwuznaczność interpretacyjna, związana z różnicą pomiędzy perspektywą obiektywną a subiektywną w konstrukcjach agentywnych (której poświęciłam w całości monografię Duraj-Nowosielska 2007). W kontekście interesujących nas zdań chodzi o rozpoznanie, czy mówi się w nich o celu samego podmiotu - o jego osobistym, subiektywnym celu, o tym, czego on sam chce, czy też o tym, jak działanie podmiotu ocenia nadawca z punktu widzenia obiektywnej efektywności tego działania (przy czym oczywiście wyrazicielem tego „obiektywizmu” pozostaje na poziomie zdania sam nadawca). W tym drugim wypadku będziemy mieli do czynienia z pojęciem celowości w „obiektywnym” znaczeniu, i można by rzec, że jedno ma niewiele wspólnego z drugim. Żeby jednak zinterpretować tę różnicę - dla zrozumienia zdania mającą znaczenie zasadnicze - nie musimy odwoływać się do dwuznaczności samego przymiotnika celowy, skutkującej jego rozbiciem na dwie jednostki leksykalne; wystarczy odnieść się do podwójnego, subiektywno-obiektywnego oglądu opisywanej w zdaniu sytuacji.

Tak więc z jednej strony odnotujemy zdania „subiektywne”, w których mówi się o subiektywnym celu podmiotu; wśród nich rozróżnimy dalej cele wewnętrzne i zewnętrzne wobec tego, co wyrażone w zdaniu (jak to wyjaśniałam powyżej). Z drugiej strony odnotujemy konstrukcje „obiektywne", gdzie podstawą predykacji jest jakiś skutek w rzeczywistości (faktyczny bądź - w zdaniach niedokonanych - przewidywany przez nadawcę): na podstawie takiego przewidywanego skutku możemy na przykład powiedzieć, że $\mathrm{x}$ budzi $\mathrm{y}-\mathrm{ka}$, jeżeli stuka $\mathrm{w}$ ścianę i nawet nie wie, że y śpi nieopodal. Na tej zasadzie będziemy też mówić o celowości czyichś działań (samo to wyrażenie odnosi się do takiego właśnie znaczenia obiektywnego): działanie jest celowe, o ile w opinii nadawcy jest takie, że zmierza do określonego celu, co ważne - celu przez niego samego projektowanego; kto inny jest tu zatem wykonawcą czynności, kto inny zaś wytycza hipotetyczny cel. Nie oznacza to bynajmniej, że podmiot ma ten cel realizować, tj. nie chodzi o delegowanie sprawczości, ale o ocenę post factum skutków jego działania (całkowitych $\mathrm{w}$ aspekcie dk, częściowych $\mathrm{w}$ ndk). Zupełnie niezależnie podmiot danego działania może mieć swoje własne subiektywne cele związane z tym działa- 
niem (pokrywające się z celami nadawcy lub rozmijające się z nimi), jednak o nich w zdaniu się milczy.

W przywołanych przykładach (25)-(27) przymiotnik wchodzi w zakres konstrukcji subiektywnej, z zaznaczającą się różnicą celu wewnętrznego i zewnętrznego. Jednak już w zdaniu (cytowanym):

(28) Celowe jest stworzenie systemu zachęt dla kierowników jednostek i innych pracowników uczelni,

w którym przymiotnik stoi w pozycji orzecznikowej, mowa jest oczywiście o tym, że sam nadawca ocenia te działania jako takie, które prowadzą do jakiegoś (w domyśle: pożądanego) celu; pożądanego właśnie z tego powodu, że wyznacza go sam nadawca. Jest to zatem zdanie „obiektywne”, por. z analogicznym „subiektywnym” zdaniem, w którym przymiotnik zajmuje pozycje atrybutywną:

(29) Było to celowe tworzenie systemu zachęt dla pracowników.

Widać więc, że dla przymiotnika możliwe są aż trzy interpretacje, w zależności od tego, czy mamy do czynienia z subiektywnym celem wewnętrznym, subiektywnym celem zewnętrznym, czy z celem obiektywnym. Jeśli chodzi o ten ostatni, będzie on zawsze zewnętrzny wobec wyrażonego w zdaniu działania, skoro nadawca ocenia w nim działanie z punktu widzenia własnych hipotetycznych celów; dlatego zdania obiektywne są zawsze „zewnątrzcelowe”.

Tak jak zaznaczyłam, owa trójznaczność dotyczy wyłącznie przymiotnika. Zdanie:

(30) Celowo stworzono system zachęt dla pracowników. / System zachęt stworzono celowo

wyrażać już będzie wyłącznie subiektywny cel podmiotu (zob. zestawienie na końcu).

Warto jeszcze raz podkreślić, że kiedy mowa o tych różnicach, w istocie nie chodzi o dwuznaczność samego przysłówka czy przymiotnika (znajdującą odzwierciedlenie w opisie semantycznym poszczególnych jednostek), lecz 
o pewne regularne własności kontekstów zdaniowych, które wpływają na określone rozumienie celu. Rozróżnienie perspektywy obiektywnej i subiektywnej daje o sobie znać niezależnie od pojęcia celowości, toteż nie musimy szukać wytłumaczenia interesujących nas zjawisk w dwuznaczności samych wyrażeń, nawet jeśli te dwa znaczenia zdają się być bardzo od siebie odległe (dążylibyśmy tu raczej do ustalenia maksymalnie ogólnej formuły semantycznej). Z kolei na interpretację celu wewnętrznego i zewnętrznego będzie miał wpływ sam czasownik, chociaż - o czym pisałam - jak najbardziej można napotkać konteksty pod tym względem niejednoznaczne.

To jednak, że takie konteksty istnieją, nie oznacza, że odbiorca przechodzi nad nimi do porządku. Niewykluczone, że pewne zdania pozostaną interpretacyjnie niejednoznaczne bez większej szkody dla skuteczności komunikacyjnej, ale normalnie skłaniamy się ku interpretacji na zasadzie alternatywy wykluczającej: odbiorca po prostu jest zainteresowany rozstrzygnięciem, o jakie rozumienie chodzi. Jeżeli kontekst zdania okazuje się niejednoznaczny, konsekwentnie zaburza to jego odbiór (kilka tego rodzaju przykładów podam dalej) - omawiane różnice nie są zatem kwestią nieokreśloności znaczeniowej, która może taką pozostać w procesie komunikacji, lecz rzeczywistej dwuznaczności całych zdań, domagającej się rozstrzygnięcia (choć niekoniecznie - co podkreślam - mającej swój wyraz w semantycznym opisie samego wyrażenia).

Jak wspominałam, jest kilka czynników, które mogą wpływać na interpretację tego rodzaju wypowiedzi; nie będę ich w tej chwili omawiać, wspomnę tylko krótko o łączliwości ze zdaniami celowymi (w związku z rozróżnianiem celu wewnętrznego i zewnętrznego), ponieważ temat ten wypłynął już tutaj wcześniej. Porównajmy autentyczne zdania:

(31) Brytyjski lekarz celowo wpuścił do swojego organizmu różne paso$\dot{z} y t y$, by pokazać telewidzom i internautom, w jaki sposób niszczq one ciało.

(32) Gdy nie poszło mu w pierwszym secie, celowo oddat drugiego, by zebrać się w sobie do następnego.

(33) Producenci celowo postarzaja sprzęt, by umierat tuż po gwarancji.

Jeśli potraktujemy te zdania jako „normalne” zdania celowe, wyrażające jakiś dalszy cel podmiotu, to cel ten w interpretacji odbiorcy nie będzie - tak sądzę - dublował znaczenia przysłówka; przysłówki będą w takiej sy- 
tuacji rozumiane „wewnątrzcelowo”, inaczej niż w przykładach takich jak (3), w których zdania podrzędne celowe interpretowane są na zasadzie dopowiedzenia, precyzującego znaczenie przysłówka. Istotne jest właśnie to, jaki kontur intonacyjny ma zdanie z ewentualnym składnikiem celowym. Por.:

\section{$\searrow \nearrow$}

(34a) Myślę, że barak podpalono celowo, aby ułatwić ucieczkę aresztowanym.

\section{$\nearrow \searrow /$}

(34b) Myślę, że barak podpalono celowo - aby ułatwić ucieczkę aresztowanym.

W zdaniu (34a), z antykadencją, uzupełnienie celowe wchodzi w kontur zdania głównego, przysłówek zyska więc interpretację „wewnątrzcelową", tak jak (31)-(33). Z kolei w zdaniu (34b), z kadencją i pauzą po niej, samo zdanie celowe jest dopowiedzeniem, precyzującym to, co kryje się w treści przysłówka, który w takiej sytuacji będzie rozumiany „zewnątrzcelowo”. Są to pewne tropy, jakie może wziąć pod uwagę odbiorca (naturalnie nieświadomie) w poszukiwaniu właściwej interpretacji, o ile ta nie nasuwa się kontekstowo z odpowiednią dozą oczywistości. Problem precyzowania znaczenia zdań niejednoznacznych to jednak osobny, duży temat - tutaj podkreślam tylko tyle, że konstrukcje z wyrażeniami celowo, celowy domagają się precyzacji - kontekstowej czy innej - jeśli chodzi o zlokalizowanie celu.

6. Kolejne wyrażenie, które nas w tym miejscu będzie interesowało, to przysłówek niecelowo. Wspominałam, że przysłówki „nieintencjonalne” mają zasadniczo tendencję do zajmowania w zdaniu pozycji tematycznej, chociaż nie dotyczy to ich wszystkich - niecelowo, niespecjalnie czy nienaumyślnie zdają się tej zasadzie nie podlegać. Trudno uznać za sensowne zdanie zaakcentowane w ten sposób:

(35) [Co się stało?] ? Jan niecelowo stłukł wazon. (Vs.: + Jan niechcący stłukł wazon.)

To pokazuje, że pewne przysłówki „nieintencjonalne” są w stanie funkcjonować samodzielnie i można je bez wcześniejszego kontekstu zastosować 
do pewnych sytuacji (jak niechcqcy, nieświadomie), inne natomiast funkcjonują wyłącznie na zasadzie zaprzeczenia zadanego myślowo konkretnego przysłówka intencjonalnego. Tak jest właśnie z niecelowo, które trudno sobie wyobrazić w zdaniach bez kontekstowego „pozytywnego” tła. Nie powiedzielibyśmy zatem normalnie:

(36a) ? Jan niecelowo napisal ten list.

(37a) ? Jan niecelowo bębnil palcami o stól,

por. z jednej strony ze zdaniami z akcentowanym przysłówkiem:

(36b) Jan napisal ten list niecelowo.

(37b) Jan niecelowo bębnił palcami o stół., a z drugiej - z akceptowalnymi:

(38) Jan niechcący uderzył palcami o stól.

(39) Jan nieświadomie bębnił palcami o stół.

Zdania (36b)-(37b), z zaakcentowanym przysłówkiem i czasownikiem, znaczą: ,x zrobił p (napisał list) / robił p (bębnił palcami) i zrobił / robił to nie po to, żeby spowodować dane q"; w przeciwieństwie do przysłówka niezaprzeczonego, q nie może pozostać tu nieokreślone, tj. nadawca zawsze będzie miał na myśli pewien hipotetyczny cel, któremu dalej decyduje się zaprzeczyć. W zdaniu:

\section{(40) Jan niecelowo machnął wtedy ręką}

chodzi o to, że Jan nie zrobił tego po to, żeby spowodować określone q, czyli np. dać komuś coś do zrozumienia - podstawą jest więc założenie, że mógt 
w ten sposób chcieć dać komuś coś do zrozumienia. W sensie niezależnym od tak zadanego kontekstu (analogicznie do niechcqcy czy nieświadomie) zdania z niecelowo odbieram jako dewiacyjne, por.:

(41) ? Kasia usiadła obok Jana i on wtedy niecelowo machnął ręką, wytrącając jej z ręki filiżankę <>

(42) Kasia usiadła obok Jana i on wtedy niechcący / mimowolnie machnął ręką, wytrącając jej z ręki filiżankę.

To oznacza, że niecelowo funkcjonuje bardziej na zasadzie zaprzeczenia wprost (określonemu celowi) niż na zasadzie braku celu. Żeby to pokazać, można pokusić się o zbudowanie testu negacyjnego, ale wbrew pozorom nie jest to wcale proste:

(43) ? Jan niecelowo machną wtedy ręką, zresztą nikomu nie przyszło na myśl, że mógłby to robić w jakimś celu;

w takim sformułowaniu (mimo wszystko najlepszym, jakie przychodzi mi do głowy) zdanie to jest jednak ,do wyratowania”, bo wbrew dosłownej interpretacji w naturalny sposób pozostawia poza zakresem wyrażenia nikt samego nadawcę.

6.1. Przykłady (35)-(43) to zdania z czasownikami sugerującymi intencję podmiotu albo zdania z czasownikami akcyjnymi. I podobnie jak to było z przysłówkiem celowo, zdania zbudowane wokół czasowników neutralnych, jeśli chodzi o postawę intencjonalną podmiotu, będą odczytywane inaczej. Przypomnijmy bezpośrednie zaprzeczenia celowo w (20)-(21): pierwsza interpretacja tych zdań dotyczyła czasownika z powierzchni zdania; inne rozumienie może trudno całkiem wykluczyć, jednak w zwykłych warunkach było ono raczej mało prawdopodobne. Co się zaś tyczy wyrażenia niecelowo, to wydaje się, że mamy tu do czynienia z rzeczywistą dwuznacznością odnośnych zdań. I tak, zdania: 
(44) Jan stłukł ten wazon niecelowo

(45) Jan niecelowo zadrwił sobie z Leszka

rozumiemy albo w ten sposób, że:

„x przez to, że zrobił jakieś p, spowodował q [stłuczenie wazonu]

i x nie robił p po to, żeby spowodować q" (wyrażone w zdaniu $\rightarrow$ cel wewnętrzny),

albo tak:

„X zrobił p (stłukł wazon)

i x zrobił p nie po to, żeby spowodować dane q" ( $\rightarrow$ cel zewnętrzny).

Chodzi tu zatem o znaną już alternatywę celu zewnętrznego i wewnętrznego, dotyczącą oczywiście subiektywnych celów podmiotu. Ponadto - co ciekawe - w odróżnieniu od przysłówka niezaprzeczonego zdarzają się użycia obiektywne tego wyrażenia, takie jak cytowane z prasy:

(46) Było nielegalnie, nierzetelnie, niecelowo i niegospodarnie.

Jak się domyślamy, chodzi tu nie o to, że sam (sugerowany) podmiot działania nie wyznaczył sobie żadnego celu, tylko o przewidywany przez nadawcę brak skuteczności tego działania. W moim odczuciu jednakże są to dziwne użycia (zresztą bardzo rzadkie), i niecelowo na ogół występuje w kontekstach subiektywnych (zob. ponownie tabelę na końcu).

6.2. Okazuje się natomiast, że znacznie więcej tego rodzaju „obiektywnych" wystąpień ma przymiotnik niecelowy - tak przynajmniej wynika z różnych zanotowanych przeze mnie kontekstów użycia, np.:

(47) Sad uznat, że przywrócenie pracownika do pracy byłoby niecelowe.

(48) Te środki do walki z bezrobociem sq wedtug nas niecelowe, względnie nierealne. 
(49) Propozycje MEN uważamy za niecelowe i szkodliwe.

Niemniej jednak wydaje się, że w każdym z tych zdań można bez zmiany treści (założonej przez nadawcę) zastąpić słowo niecelowy słowem bezcelowy, które - jak zaraz pokażę - specjalnie obsługuje takie właśnie konteksty obiektywne. Podobnie jak to było z przysłówkiem niecelowo, użycia (47)-(49) w mojej intuicji są raczej chybione, i mając na uwadze precyzję, powinno się te jednostki konsekwentnie rozdzielać. Zatarcie różnicy pomiędzy nimi, a co za tym idzie - używanie przymiotnika niecelowy w znaczeniu obiektywnym czasami powoduje zabawne wręcz dwuznaczności tekstowe, por. autentyczne przykłady:

(50) Prezydent Saakaszwili jest podejrzewany o niecelowe wydawanie środków budżetowych.

(51) Sad uznat za niecelowe wszczęcie postepowania egzekucyjnego.

(52) Za niecelowa egzekucje dtugu płaci wierzyciel.

W (50) może chodzić albo o to, że w rozumieniu nadawcy prezydent wydawał te pieniądze „,bez sensu”, nieefektywnie, albo o to, że wydawał je niecelowo w sensie: tak naprawdę nie chciał ich wydawać, wydawanie ich nie było jego subiektywnym celem.

Podobnie dwuznaczne, a przez to w pierwszym momencie niezrozumiałe, jest zdanie (51). Może być ono oświadczeniem łagodzącym przewinienie $\mathrm{x}$-a: $\mathrm{x}$ wszczął postępowanie egzekucyjne wobec y-ka niecelowo, tzn. wszczynając postępowanie wobec y-ka, nie chciał przez to osiągnąć egzekucji długu od y-ka (tylko np. od z-a, czyli zrobił to pomyłkowo); tak jak wspominałam, to znaczenie ma swój odpowiednik przysłówkowy. Równie dobrze jednak może ono być stwierdzeniem obciążającym x-a: wszczęcie postępowania egzekucyjnego było tak przeprowadzone, że nie mogło prowadzić do pożądanego celu; i tu raczej nie znajdujemy odpowiednika przysłówkowego, zob. wyżej. Różnica zasadnicza!

$\mathrm{Na}$ tej samej zasadzie nie wiadomo właściwie, za co ma płacić wierzyciel w zdaniu (52): czy płaci on wtedy, gdy pomyłkowo (niecelowo) wyegzekwował dług od danego x-a, czy też płaci w sytuacji, gdy ta egzekucja „,chybiała celu”, tj. była oceniana jako z samej swej istoty (zob. dalej) nieskuteczna. 
7. Tak jak już zasygnalizowałam, tego rodzaju obiektywnym kontekstom odpowiada przede wszystkim przysłówek bezcelowo, wraz ze swoim przymiotnikowym korelatem bezcelowy (te dwa wyrażenia wydają się analogiczne, w tym zakresie, w jakim je tutaj badam) - i na koniec krótko się im przyjrzymy. Oto kilka cytowanych zdań z ich użyciem:

(53) Kręcit się bezcelowo tam i z powrotem.

(54) Wszystkie te wysitki podejmowali bezcelowo.

(55) Dzieciaki przesiaduja tam bezcelowo.

(56) Co robia ludzie siedzacy bezcelowo na ławce?

(57) Ograniczanie emisji gazów cieplarnianych jest zupetnie bezcelowe.

(58) Ferie to bezcelowy relikt przeszłości.

Wstępnie zaproponowałabym następujące przybliżenie znaczenia tych wyrażeń:

\section{$x$ robip}

i przez to, że robi p, nie powoduje skutku q

takiego, jakiego można oczekiwać w danej sytuacji.

Na przykład dla zdania (54): „x, y robili p (podejmowali wysiłki) / i to, że robili $\mathrm{p}$, nie powodowało oczekiwanego skutku". Tak więc nie chodzi tu o to, że podmiot nie dążył do żadnego celu (w tym przykładzie z pewnością dążył), tylko o samą ocenę nadawcy - bezcelowo odnosiłoby się właśnie, w mojej terminologii, do perspektywy obiektywnej konstrukcji agentywnych. Przedstawiona formuła oddaje też to, że przysłówek ten występuje raczej z aspektem niedokonanym, podczas gdy celowo i niecelowo miały pod tym względem dość swobodną łączliwość, por.: ? On to zrobił bezcelowo <> On to robił bezcelowo.

Przymiotnik zachowuje się pod tym względem analogicznie: bezcelowe działanie (bezcelowe wysitki, bezcelowa gonitwa itd.) to takie działanie, które nie przynosi oczekiwanego rezultatu. 
W słownikach podawane są na ogół synonimy takie jak: daremny, bezowocny, bezskuteczny ${ }^{15}$. Można by się jednak zastanowić, czy rzeczywiście są one trafne (i podobnie: daremnie, bezowocnie, bezskutecznie dla przysłówka) - w orzekanej w zdaniach tego typu „bezcelowości” wydaje się bowiem tkwić coś więcej. Poniższą wypowiedź na przykład oznaczyłabym jako semantycznie nieakceptowalną (choć jest autentyczna):

(59) [?] Pamiętam, jak kiedyś bezcelowo szukałem tego utworu-

najwidoczniej „bezskuteczny” to mimo wszystko nie to samo co „,bezcelowy". Skoro podmiot rzeczywiście - jak sam twierdzi - szukat tego utworu (i potraktujemy serio słowo szukał oraz założymy, że autor zdania również traktował je serio), to jego wysiłek mógł się w końcu okazać daremny i nieskuteczny, ale samo ostateczne rozminięcie się z celem nie wystarczy tu do orzeczenia bezcelowości działania. (Podmiot mógł też oczywiście „kręcić się bezcelowo", jakby czegoś szukał, bądź w ogóle udawać, że czegoś szuka... wtedy jednak mówilibyśmy o zupełnie innych sytuacjach.)

Jeżeli sam nadawca twierdzi o sobie, że czegoś szukał, a zarazem, że robił to bezcelowo, skutkuje to wyraźnym semantycznym ,zgrzytem”. Najważniejsze w „bezcelowości” jest zdystansowanie się nadawcy do działania oraz jego ocena, że $w$ danym momencie to działanie było takie, że nie mogło doprowadzić do określonego rezultatu, było jakby chybione u samego źródła i tu właśnie nie pasuje (poważnie potraktowane) słowo szuka $1^{16}$. Oczywiście, nadawca mógłby powiedzieć coś takiego: „to moje szukanie było zupełnie bezcelowe", ale wtedy rozumiemy tę wypowiedź tak, że w ogóle angażowanie się w tego rodzaju aktywność jak szukanie było jego zdaniem chybione; tymczasem autor zdania (59) wyraźnie nie to miał na myśli.

To samo dotyczy przymiotnika: kiedy mówimy na przykład, że rząd podejmuje bezcelowe działania, chodzi nam nie po prostu o to, że te działania

15 Por. np. SJP: „,bezcelowy - nie mający określonego celu; nie dający pożądanych wyników; bezskuteczny, bezowocny, daremny, niepotrzebny".

16 Podkreślić należy przy tym, że ,poważne traktowanie” słowa nie jest tu mało znaczącym warunkiem, w dodatku o „nienaukowym” brzmieniu, tylko warunkiem zasadniczym wyznaczającym ,bazową” dla języka sferę mówienia dosłownego, por. kategorię ,powagi” i mówienia serio u A. Bogusławskiego (2008: 36; 2009: 18-19), a także im Ernste sagen Fregego (1977: 108). 
nie daja pożądanych efektów, lecz o to, że te działania są takie, że - jak można oczekiwać - tych efektów w ogóle nie będzie, por.:

(60) *Rząd podejmuje działania jak na razie bezcelowe, choć miejmy nadzieję, że za jakiś czas okażą się skuteczne.

Przypomnę, że o to dokładnie chodziło w cytowanych przeze mnie wcześniej zdaniach z przymiotnikiem niecelowy:

(47) Sad uznat, że przywrócenie pracownika do pracy byłoby niecelowe czyli chybiałoby celu; przywrócenie pracownika byłoby takim działaniem, że - jak można przewidywać - nie da ono pożądanych rezultatów. Podobnie, zdanie:

(48) Te środki do walki z bezrobociem sq wedtug nas niecelowe, względnie nierealne

rozumiemy tak, że wspomniane środki nie tylko okazuja się nieskuteczne, ale też są takie, że zdaniem nadawcy nie moga być skuteczne. Tego rodzaju ocena może zostać wydana, zanim w ogóle zostaną one wdrożone, gdy tymczasem rzeczywistej efektywności nie da się w ten sposób - „na wyrost”ocenić.

Wygląda więc na to, że wcześniejszą formułę należałoby zmodyfikować:

\section{x robi p}

i p jest takie, że można myśleć, że p nie spowoduje skutku q takiego, jakiego można by oczekiwać w danej sytuacji.

Zostawiając te semantyczne detale, widzimy, że i w bezcelowo, i w bezcelowy mowa jest o (niedoszłym) skutku czynności: nadawca ma w nich na myśli przewidywaną efektywność działania, stąd obydwa wyrażenia związane są z perspektywą obiektywną. Pomija się w nich całkowicie to, czego chce (czy czego nie chce) sam podmiot, por. np.:

(61) ? Siedział przy stole i machał sobie bezcelowo noga - 
machanie sobie nogą najwyraźniej nie jest czynnością, której efekty normalnie podlegałyby obiektywnej weryfikacji (por. z dyskutowanym wcześniej zdaniem [16]).

8. Do subiektywnego celu samego podmiotu, ściślej do jego braku, odnosi się inne, analogiczne wyrażenie - mianowicie bez celu, por.:

(62) Wałęsał się bezcelowo tam i z powrotem. $<>$

(63) Wałęsał się bez celu tam i z powrotem.

W drugim zdaniu chodzi o to, że sam podmiot nie miał celu w tym, co robił; w pierwszym - o „obiektywną bezcelowość” akcji.

Co się tyczy natomiast rozróżnienia celu wewnętrznego i zewnętrznego, to wszystkie te trzy wyrażenia, tzn. bezcelowo, bezcelowy i bez celu odnoszą się do celu zewnętrznego; w dwóch pierwszych wynika to z ich „obiektywno-agentywnej" semantyki, ale taką właściwość ma także wyrażenie bez celu (bez celu = bez pomyślanego ,dalszego" celu ${ }^{17}$ ).

Co więcej, wydaje się, że ta cecha trzech wymienionych wyrażeń nie zależy wcale od typu czasownika, do którego się one odnoszą, tak jak to obserwowaliśmy w poprzednio analizowanych jednostkach. Porównując wyrażenia bezcelowe niszczenie cudzej własności oraz niecelowe niszczenie cudzej własności, rozumiemy, że w „niecelowym niszczeniu” chodzi o to, że nie ono było subiektywnym celem podmiotu ( $\rightarrow$ interpretacja subiektywna „wewnątrzcelowa”, oparta na odkauzatywnym charakterze czasownika); w ,bezcelowym niszczeniu” chodzi natomiast o to, że sam nadawca nie widzi żadnego sensownego celu w niszczeniu cudzej własności $(\rightarrow$ interpretacja obiektywna ,zewnątrzcelowa”) - w tym ostatnim cele samego agensa nie są istotne, mimo że oczywiście mógł on mieć w tego rodzaju działalności jakiś własny cel.

9. Podsumowuję. Interesowały nas tutaj cztery przysłówki odnoszące się do celu (zob. tabelę poniżej): celowo, niecelowo, bezcelowo i bez celu. Spośród nich celowo i niecelowo mogą wskazywać albo na subiektywny cel

${ }^{17}$ Naturalnie, dojdą tu jeszcze pewne dodatkowe ograniczenia selekcyjne, w które w tej chwili nie wnikam. 
wewnętrzny, zawarty w zdaniu, albo cel zewnętrzny względem tego, na co wskazuje zdanie. W odpowiadających tym przysłówkom przymiotnikach dochodzi do tego jeszcze różnica pomiędzy perspektywą subiektywną, tj. podmiotową, a obiektywną - nadawczą, która z kolei zawsze wiążę się z celem zewnętrznym.

Pociąga to za sobą wyraźne różnice w rozumieniu zdań, a czasami dwuznaczności interpretacyjne; jednak same przysłówki wskazują raczej na cel wyznaczony przez podmiot działania.

Wyrażenia bezcelowo i bez celu z kolei zagospodarowały swoje pole semantyczne w ten sposób, że bezcelowo odnosi się do konstrukcji obiektywnych, wprowadzając ocenę nadawcy co do skuteczności działania agensa, natomiast bez celu wskazuje na nieobecność celu z punktu widzenia samego tego agensa. Obydwie te jednostki odnoszą się do jakiegoś hipotetycznego celu zewnętrznego wobec tego, na co wskazuje predykat zdaniowy. Porównajmy:

$\begin{array}{ccc}\text { perspektywa } & \text { perspektywa } & \text { perspektywa } \\ \text { subiektywna } & \text { subiektywna } & \text { obiektywna } \\ \text { cel zewn. } & \text { cel wewn. } & \text { (cel zewn.) }\end{array}$

celowo

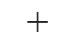

celowy

niecelowo

$+$

$+$

$+$

$+$

$?$

niecelowy

$+$

$+$

$(+)$

bezcelowo

bezcelowy

bez celu

Jak widać, jednoznaczne są tylko wyrażenia bezcelowo, bezcelowy i bez celu; z kolei najbardziej narażone na dwuznaczność są przymiotniki celowy i niecelowy, bo możliwe w nich są aż trzy interpretacje. Istotnie - tak jak pokazywałam - niektóre przykłady z prasy czy internetu są w pierwszej chwili niezrozumiałe, przynajmniej jeśli pominąć szerszy kontekst wypowiedzi, 
dzięki któremu można oczywiście tego rodzaju zdania ujednoznacznić. Odwołać się do kontekstu z zamiarem poszukania właściwej interpretacji można zawsze, nie zmieni to jednak faktu, że wymienne stosowanie wyrażeń niecelowy i bezcelowy nie sprzyja precyzji komunikacyjnej.

\section{Bibliografia}

Austin J., 1977, Jestem niewinny, Znak 29, s. 667-696.

BogusŁawski A., 1977, Problem of the Thematic-Rhematic Structure of Sentences, Warszawa: PWN.

Bogusıawski A., 1991, Semantic Primes for Agentive Relations, Lingua Posnaniensis XXXII/XXXIII, Poznań, s. 39-64.

BogusŁawski A., 1999, Inherently thematic or rhematic units of language, w: E. Hajičova et al. (red.), Travaux du Circle Linguistique de Prague 3, Amsterdam, s. 211-224.

BogusŁawski A., 2003, Aspekt i negacja, Warszawa: KLF UW.

BogusŁawski A., 2008, Semantyka, pragmatyka. Leksykografa głos demarkacyjny. Warszawa: BEL Studio.

Bogustawski A., 2009, Myśli o gwiazdce i regule, Warszawa: BEL Studio.

Danto A. C., 1963, What Can We Do, The Journal of Philosophy 60, s. 435-448.

Davidson D., 1966, The Logical Form of Action Sentences, w: N. Rescher (red.), The Logic of Decision and Action, Pittsburgh: University of Pittsburgh Press.

Duraj-Nowosielska I., 2007, Robić coś $i$ coś powodować. Opozycja agentywności i kauzatywności w języku polskim. Warszawa: Wydział Polonistyki UW.

Duraj-Nowosielska I., 2012, Nie przypadkiem o niechcacy. Szkic semantyczny, Warszawa: Wydawnictwo UKSW.

Duraj-Nowosielska I., 2013, O teście negacji, kontekstach interpretacyjnych i zdaniach „wyratowanych”, Linguistica Copernicana 2(10), s. 161-191.

EJP -Urbańczyk S., Kucata M. (red.), Encyklopedia Języka Polskiego, 1999, Wrocław-Warszawa-Kraków-Gdańsk: Ossolineum.

Frege G., 1977, Pisma semantyczne, przeł. B. Wolniewicz, Warszawa: Państwowe Wydawnictwo Naukowe.

Grochowski M., 1980, Pojęcie celu. Studia semantyczne, Wrocław-Warszawa-Kraków-Gdańsk: Ossolineum.

Hampshire S., 1959, Thought and Action, London: Chatto \& Winds.

Klemensiewicz Z., 1968, Zarys składni polskiej, Warszawa: Państwowe Wydawnictwo Naukowe. 
Ryle G., 2000, Courses of Actions or the Uncatchableness of Mental Acts, w: A. O'Hear (red.), Philosophy - The Journal of the Royal Institute of Philosophy, t. 75/293, s. 331-344.

SAcks O., 1996, Mężczyzna, który pomylit swoja żonę z kapeluszem, Poznań: Zysk i S-ka.

SeArle J., 1983, Intentionality. An Essay in the Philosophy of Mind, Cambridge-New York: Cambridge University Press.

SJP - Szymczak M. (red.), Słownik Języka Polskiego, 1992, Warszawa: Państwowe Wydawnictwo Naukowe.

WróBel H., 1999, Czasownik, w: R. Grzegorczykowa, R. Laskowski, H. Wróbel (red.), Gramatyka współczesnego języka polskiego. Morfologia, t. II: Słowotwórstwo, Warszawa: Państwowe Wydawnictwo Naukowe, s. 536-583.

\section{Where is the 'cel' [purpose] in Sentences with celowo [purposefully] and Several More Questions on the Related Expressions}

( $\left.\begin{array}{lllllll}\mathbf{s} & \mathbf{u} & \mathbf{m} & \mathbf{m} & \mathbf{a} & \mathbf{r} & \mathbf{y}\end{array}\right)$

In the article I discuss selected aspects concerning the semantics of expressions related to the notion of purpose in Polish: celowo [purposefully], celowy [purposeful], niecelowy, bezcelowy [purposeless], niecelowo, bezcelowo, bez celu [purposelessly] (in rough approximation of meaning). My starting point is the question mentioned in the title, i.e. where to "locate" the purpose one has in mind in sentences with celowo [purposefully]: whether it is external to what is indicated by the sentence predicate (ktoś powiedziat coś celowo 'somebody said something purposefully' $\rightarrow$ somebody said something [p] in order to achieve something else [q], something other than the mere fact of saying p), or whether we mean the internal purpose, related strictly to the predicate (somebody destroyed something on purpose $\rightarrow$ somebody wanted to destroy it, destroying it was his purpose here). The ambiguity of sentences with the adverb celowo, as well as the adjective celowy, can be resolved by identifying the type of the verb in the position of sentence predicate. However, this is not a completely reliable test, and one can always come across sentences ambiguous in that matter (cf. celowe działanie $\rightarrow$ 'action on purpose', action having purpose in itself, or 'purposeful action', action directed towards some purpose). All the expressions mentioned above are being further analyzed in terms of "purpose localization".

This kind of distinction is followed by another one, connected with sentence perspective - either objective or subjective. What matters here is whether the speaker has in mind the agent's purpose (external or internal $\rightarrow$ subjective perspective), or whether the speaker ignores the subject's goals and estimates his action from the point of view of some objective aims fixed by the speaker himself, as in sentences: Rzad podejmuje bezcelowe działania [The government undertakes purposeless ac- 
tions] or Przywrócenie pracownika do pracy bytoby niecelowe [Bringing the employee back to work would be purposeless].

Finally, we have three different "purpose locations" in sentences with the expressions in question, thus, three different "types of purpose": subjective internal purpose, subjective external purpose and the objective one (the latter being always external to what is indicated by the sentence). Some of the analyzed expressions point to the type of purpose unambiguously (bezcelowo, bezcelowy, bez celu), others are ambiguous, expressing one of the two (celowo, niecelowo) or even three senses (celowy). 